\title{
Bioprocess and biotechnology: effect of xylanase from Aspergillus niger and Aspergillus flavus on pulp biobleaching and enzyme production using agroindustrial residues as substract
}

\author{
Nelciele Cavalieri de Alencar Guimaraes ${ }^{1}$, Michele Sorgatto ${ }^{1}$, Simone de Carvalho Peixoto-Nogueira², \\ Jorge Henrique Almeida Betini ${ }^{2}$ Fabiana Fonseca Zanoelo ${ }^{1}$, Maria Rita Marques ${ }^{1}$, \\ Maria de Lourdes Teixeira de Moraes Polizeli ${ }^{2}$ and Giovana C Giannesi ${ }^{*}$
}

\begin{abstract}
This study compares two xylanases produced by filamentous fungi such as A. niger and A. flavus using agroindustrial residues as substract and evaluated the effect of these enzymes on cellulose pulp biobleaching process. Wheat bran was the best carbon source for xylanase production by A. niger and A. flavus. The production of xylanase was 18 and $21 \%$ higher on wheat bran when we compare the xylanase production with xylan. At $50^{\circ} \mathrm{C}$, the xylanase of $A$. niger retained over $85 \%$ activity with $2 \mathrm{~h}$ of incubation, and $A$. flavus had a half-life of more than 75 minutes. At $55^{\circ} \mathrm{C}$, the xylanase produced by $A$. niger showed more stable than from A. flavus showing a half-life of more than 45 minutes. The xylanase activity of $A$. niger and A. flavus were somehow protected in the presence of glycerol $5 \%$ when compared to the control (without additives). On the biobleaching assay it was observed that the xylanase from A. flavus was more effective in comparison to A. niger. The kappa efficiency corresponded to 36.32 and 25.93 , respectively. That is important to emphasize that the cellulase activity was either analyzed and significant levels were not detected, which explain why the viscosity was not significantly modified.
\end{abstract}

Keywords: Aspergillus niger; Aspergillus flavus; Agroindustrial residues; Wheat bran; Biobleaching

\section{Introduction}

Annually, large quantities of lignocellulosic wastes (agricultural and agroindustrial residues, like wheat bran, sugarcane bagasse, soybean, rice straw, corncob and orange peel) are generated through industrial processes such as breweries, paper-pulp, textile and timber industries. And their disposal is becoming a problem regarding space, causing environmental pollution because most of the wastes are disposed by burning. However, the plant biomass regarded as "wastes" are biodegradable and represent an inexpensive alternative source for microbial growth or enzymes production (Sepahy et al., 2011; Facchini et al., 2011; Okafor et al., 2007).

\footnotetext{
*Correspondence: giannesigiovana@hotmail.com

'Laboratory of Biochemistry, CCBS - Universidade Federal de Mato Grosso do Sul/UFMS, Av Costa e Silva s/n, 79070-900, Campo Grande, MS, Brazil Full list of author information is available at the end of the article
}

In the last decades, an increasing number of studies aimed to develop environmentally clean and non-toxic methods for industrial processes (Betini et al., 2009; Peixoto-Nogueira et al., 2009). The possibility of using a variety of agricultural residues is an attractive practice for the production of plant cell wall degrading hydrolytic enzymes, especially xylanase and cellulase, because this system could simulate the natural environment (Facchini et al., 2011, 2012).

The xylanase production has been reported for bacteria (Sepahy et al., 2011), actinomycetes (Garg et al., 2011) and fungi (Das et al., 2013; Sorgatto et al., 2012; Facchini et al., 2011, 2012). Filamentous fungi which produce xylanases are attracting greater attention than bacteria and yeast because they are particularly interesting from an industrial point of view, due to the fact they secrete much higher xylanolytic enzymes into the medium (Okafor et al., 2007; Polizeli et al., 2005). 
Among the filamentous fungi employed to produce xylanase, the Aspergillus genus is one of the most explored (Sandrim et al., 2005; Betini et al., 2009; Peixoto-Nogueira et al., 2009; Michelin et al., 2010). To date, however, there have been few reports of xylanases produced by Aspergillus flavus.

Xylanases produced by microorganisms has attracted a great deal of attention during the past few decades because of its potential biotechnological applications in various industries including food, feed, fuel, textile, and paper and pulp industries and in waste treatment (Yeasmin et al., 2011; Facchini et al., 2011; Michelin et al., 2010; Jiang et al., 2010).

An increasing awareness on environmental pollution has enforced the pulp and paper industries to strive for an alternate greener technology which will replace the use of harsh chemicals in their processes with microbial enzymes. The application of biocatalysts not only makes the process less toxic but also decreases costs associated with the production and consumption of resources (water, electricity, fuels) (Birijlall et al., 2011).

At present, bleaching process for kraft pulp uses large amounts of chlorine-based chemicals and sodium hydrosulfite, which are toxic, mutagenic, and persistent; they also cause numerous harmful disturbances in biological systems (Yeasmin et al., 2011). The enzymatic step in the process of cellulose pulp bleaching contributes to reduce the use of chlorine-containing reagents (PeixotoNogueira et al., 2009). Xylanases aid in catalyze the hydrolysis of glycosidic bonds in the xylan backbone, reducing the degree of polymerization of the substrate, enhancing the brightness of pulp (facilitating the chemical extraction of lignin from pulp in subsequent alkaline extraction) and diminish impurities. Cellulose-free, alkali and thermo-stable microbial xylanases are mostly ideal for biopulping and bleaching processes (Birijlall et al., 2011; Yeasmin et al., 2011; Peixoto-Nogueira et al., 2009).

This paper shows an important comparing of the xylanase production by $A$. niger and $A$. flavus using agroindustrial residues as carbon sources and tested their suitability for cellulose pulp biobleaching. These fungi produced xylanases with special characteristics, such as high $\mathrm{pH}$ stability and high optimum temperature, in comparison to others reported in the literature (Facchini et al., 2011; Sepahy et al., 2011). And the xylanase activity from $A$. niger was the most thermostable of three enzyme samples (A. niger, A. flavus and A. japonicus var aculeatus, studied before in our laboratory).

\section{Materials and methods Microorganisms}

Aspergillus niger and Aspergillus flavus strains were isolated by us from soil samples, identified in the Federal University of Pernambuco - UFPE (PE, Brazil) and deposited in our laboratory fungi collection. Stock cultures were propagated at $30^{\circ} \mathrm{C}$ on slants of solid potato dextrose agar (PDA) media and stored at $4^{\circ} \mathrm{C}$.

\section{Xylanase production and enzyme extraction}

Spores were inoculated into $125 \mathrm{ml}$ Erlenmeyer flasks containing $25 \mathrm{ml}$ media (Rizzatti et al., 2001) using $1 \%(\mathrm{w} / \mathrm{v})$ of the desired carbon sources (xylan or agroindustrial residues such as wheat bran, rice bran, sugarcane bagasse or corncob). The cultures were incubated under orbital agitation (110 rpm) condition, at $30^{\circ} \mathrm{C}$, during five (A. niger) or two days (A. flavus), already standardized in our laboratory. The media was subsequently vacuum-filtered using filter paper (Whatman $n^{\circ} 1$ ) and the crude filtrate was used for the study of the extracellular enzyme.

\section{Enzymatic assays and protein determination}

The reaction mixture consisted in $500 \mu$ of citratephosphate buffer (McIlvaine, 1921) pH 5.0 for both fungi containing $1 \%(\mathrm{w} / \mathrm{v})$ of xylan (birchwood), and $500 \mu \mathrm{l}$ of enzymatic extract appropriately diluted. Identical conditions of assay were employed for cellulase determination, using as substrate $1 \%(\mathrm{w} / \mathrm{v})$ carboxymethylcellulose. The samples were incubated at $60^{\circ} \mathrm{C}$ to determine xylanase and cellulase activity. The amount of reducing sugar released was determined using the 3,5-dinitrosalicylic acid (DNS) method (Miller, 1959), employing xylose (Sigma) (xylanase) and glucose (cellulase) as the standards. One unit of enzyme activity was defined as the amount of enzyme which releases $1 \mu \mathrm{mol}$ of reducing sugar per minute under assay condition. Specific activities were expressed as U/mg of protein. Protein concentrations were determined by the Lowry et al. (1951), using bovine serum albumin (BSA) as the standard.

\section{Effect of temperature and pH on enzyme activity}

The effects of temperature and $\mathrm{pH}$ on xylanase activity were analyzed using crude extracts from $A$. niger and $A$. flavus. The optimum temperature and $\mathrm{pH}$ for $A$. niger and $A$. flavus were $60^{\circ} \mathrm{C}$ and 5.0, respectively (results not shown). The thermal stability was determined with enzymes incubated between 45 and $55^{\circ} \mathrm{C}$ for different periods (5 to $120 \mathrm{~min}$ ). The influence of protectors on xylanolytic activities of $A$. niger and $A$. flavus was tested at 55 and $50^{\circ} \mathrm{C}$, respectively, during 120 minutes in the presence of $5 \%$ glycerol or polyethyleneglycol. The $\mathrm{pH}$ stability was analyzed using McIlvaine buffer in the $\mathrm{pH}$ range 3.0 - 8.0 for 1 hour.

\section{Biobleaching}

The amount of enzyme used from $A$. niger or $A$. flavus for this treatment was 10 units of enzyme per gram of 
dried cellulose pulp from Eucalyptus grandis. All calculations and procedures were determined according to the standard methods of Technical Association of the Pulp and Paper Industry (TAPPI test methods 1996). The consistency was determined on a percent dry weight basis. The volume of enzyme or distilled water was added until it reached a $10 \%$ pulp consistency. Crude xylanase extracts from $A$. niger and $A$. flavus were added to the treated pulp and the control was prepared by adding distilled water instead of enzyme. The samples were incubated inside sealed polyethylene bags at $55^{\circ} \mathrm{C}$ for 2 hours and after that, the treated cellulose pulps were filtered on a Büchner funnel, rinsed with $200 \mathrm{ml}$ of distilled water and used for determination of kappa number and viscosity. The filtrate was used to analyze the liberation of aromatic compounds monitored by absorbance values at 237 and $465 \mathrm{~nm}$.

\section{Reproducibility of results}

All results are expressed as the means of at least three independent experiments.

\section{Results and discussion}

Xylanase production using different agroindustrial residues and substrates

When different carbon sources were tested (Table 1) it was observed that the wheat bran $1 \%$ was the best carbon source for xylanase production by $A$. niger (12.76 $\mathrm{U} / \mathrm{mg}$ of protein), followed by fine sugarcane bagasse $0.5 \%(10.64 \mathrm{U} / \mathrm{mg}$ of protein) and corncob $1 \%(10.00 \mathrm{U} /$ $\mathrm{mg}$ of protein). The production of xylanase was 18 (oat spelt xylan 1\%) and 21\% (birchwood xylan 1\%) higher on wheat bran $1 \%$ when we compare the xylanase production with xylan $(10.43$ and $10.10 \mathrm{U} / \mathrm{mg}$ of protein, respectively), which means that it can substitute the xylan efficiently. In studies with A. fumigatus RP04, the production of xylanase was only between 5 and $6 \%$ higher on agroindustrial residues (powdered corncob, wheat bran and crushed corncob) when compared with media containing birchwood xylan as carbon source (PeixotoNogueira et al., 2009). Although the xylanase production was elevated in birchwood xylan 0.5\% (15.72 U/mg of protein), the utilization of an alternative carbon source, like wheat bran or sugarcane bagasse, still is viable due

Table 1 Effect of different carbon sources on xylanase production

\begin{tabular}{|c|c|c|c|c|c|c|}
\hline \multirow[b]{2}{*}{ Carbon sources } & \multicolumn{3}{|c|}{ Aspergillus niger } & \multicolumn{3}{|c|}{ Aspergillus flavus } \\
\hline & $\begin{array}{l}\text { Activity } \\
\text { (U/ml) }\end{array}$ & $\begin{array}{l}\text { Protein } \\
(\mathrm{mg} / \mathrm{ml})\end{array}$ & $\begin{array}{l}\text { Specific activity } \\
\text { (U/mg of protein) }\end{array}$ & $\begin{array}{l}\text { Activity } \\
\text { (U/ml) }\end{array}$ & $\begin{array}{l}\text { Protein } \\
(\mathrm{mg} / \mathrm{ml})\end{array}$ & $\begin{array}{l}\text { Specific activity } \\
\text { (U/mg of protein) }\end{array}$ \\
\hline Glucose $1.0 \%$ & 0.04 & 0.37 & $0.11( \pm 0.09)$ & 0.18 & 0.79 & $0.23( \pm 0.03)$ \\
\hline Rice bran $1.0 \%$ & 2.77 & 0.67 & $4.13( \pm 0.45)$ & 0.11 & 0.97 & $0.11( \pm 0.01)$ \\
\hline Rice bran $0.5 \%$ & 1.13 & 0.54 & $2.09( \pm 0.37)$ & 0.09 & 0.97 & $0.09( \pm 0.01)$ \\
\hline Rice straw 1.0\% & 0.97 & 0.45 & $2.16( \pm 0.10)$ & 2.92 & 0.91 & $3.21( \pm 0.12)$ \\
\hline Rice straw 0.5\% & 0.48 & 0.33 & $1.46( \pm 0.39)$ & 1.87 & 0.71 & $2.63( \pm 0.02)$ \\
\hline Coarse sugarcane bagasse 1.0\% & 5.49 & 0.72 & $7.63( \pm 0.45)$ & 2.64 & 0.75 & $3.52( \pm 0.27)$ \\
\hline Coarse sugarcane bagasse $0.5 \%$ & 2.78 & 0.61 & $4.56( \pm 0.43)$ & 0.63 & 0.66 & $0.96( \pm 0.14)$ \\
\hline Fine sugarcane bagasse 1.0\% & 5.96 & 0.78 & $7.64( \pm 0.44)$ & 5.53 & 0.72 & $7.68( \pm 0.29)$ \\
\hline Fine sugarcane bagasse $0.5 \%$ & 5.32 & 0.50 & $10.64( \pm 0.45)$ & 2.33 & 0.97 & $2.40( \pm 0.09)$ \\
\hline Corncob $1.0 \%$ & 8.00 & 0.80 & $10.00( \pm 0.31)$ & 3.22 & 0.86 & $3.74( \pm 0.07)$ \\
\hline Corncob $0.5 \%$ & 5.84 & 0.64 & $9.13( \pm 0.24)$ & 1.65 & 0.62 & $2.67( \pm 0.44)$ \\
\hline Wheat bran $1.0 \%$ & 8.42 & 0.66 & $12.76( \pm 0.24)$ & 11.57 & 1.44 & $8.03( \pm 0.48)$ \\
\hline Wheat bran 0.5\% & 6.23 & 0.69 & $9.03( \pm 0.27)$ & 10.26 & 1.18 & $8.70( \pm 0.03)$ \\
\hline Xylan (oat spelt) 1.0\% & 6.05 & 0.58 & $10.43( \pm 0.31)$ & 11.71 & 0.87 & $13.46( \pm 0.38)$ \\
\hline Xylan (oat spelt) $0.5 \%$ & 6.61 & 0.59 & $11.20( \pm 0.24)$ & 10.38 & 0.87 & $11.94( \pm 0.41)$ \\
\hline Xylan (birchwood) 1.0\% & 7.27 & 0.72 & $10.10( \pm 0.13)$ & 11.22 & 0.55 & $20.40( \pm 0.21)$ \\
\hline Xylan (birchwood) 0.5\% & 9.12 & 0.58 & $15.72( \pm 0.05)$ & 11.64 & 0.74 & $15.72( \pm 0.13)$ \\
\hline Corncob $0.5 \%$ + Fine sugarcane bagasse $0.5 \%$ & 9.25 & 0.52 & $17.79( \pm 0.50)$ & 3.59 & 0.76 & $4.72( \pm 0.02)$ \\
\hline Wheat bran $0.5 \%+$ Fine sugarcane bagasse $0.5 \%$ & 9.90 & 0.52 & $19.04( \pm 0.37)$ & 10.77 & 1.23 & $8.75( \pm 0.37)$ \\
\hline Wheat bran $0.5 \%+$ Corncob $0.5 \%$ & 10.50 & 0.52 & $20.19( \pm 0.36)$ & 11.92 & 1.07 & $11.14( \pm 0.01)$ \\
\hline
\end{tabular}

A. niger and A. flavus were grown on SR liquid media (Rizzatti et al., 2001) and different carbon sources, which were incubated for five and two days, respectively, at $30^{\circ} \mathrm{C}$ under orbital agitation $(110 \mathrm{rpm})$ condition. The assays were performed at $60^{\circ} \mathrm{C}$ and Mcllvaine buffer $\mathrm{pH} 5.0$. 
to its low cost for enzyme production, reducing these wastes in the environment. For A. flavus, the xylanase production was better induced by wheat bran 1 and $0.5 \%$ (8.03 and $8.70 \mathrm{U} / \mathrm{mg}$ of protein, respectively), followed by fine sugarcane bagasse $1 \%(7.68 \mathrm{U} / \mathrm{mg}$ of protein). The fine sugarcane bagasse was autoclaved, dried and ground. The other substrates tested did not presented significant results for both fungi.

The universal suitability of wheat bran as substrate is because of its cell-wall polysaccharides that contain $40 \%$ xylan, and it does not aggregate, even under high moisture conditions, providing a large surface area (Dhillon et al., 2011; Betini et al., 2009). It is why in literature can be found a lot of works of xylanase production using wheat bran, for several Aspergillus species like, Aspergillus terreus (Sorgatto et al., 2012); Aspergillus niger BCC14405 (Khonzue et al., 2011); Aspergillus niger BC-1 (Dhillon et al., 2011); Aspergillus terricola Marchal (Michelin et al., 2010); Aspergillus foetidus MTCC 4898 (Chapla et al., 2010); Aspergillus niger (Farinas et al., 2010); Aspergillus niger DFR-5 (Pal and Khanum, 2010); Aspergillus niveus RP05 (Peixoto-Nogueira et al., 2009); Aspergillus niger, Aspergillus niveus and Aspergillus ochraceus (Betini et al., 2009) and Aspergillus ficuum AF-98 (Fengxia et al., 2008). Xylanase production on corncob and sugarcane bagasse was also reported for Aspergillus terreus (Sorgatto et al., 2012), Chaetomium sp. CQ31 (Jiang et al., 2010), Aspergillus foetidus MTCC 4898 (Chapla et al., 2010), Aspergillus terreus (Lakshmi et al., 2009), Thermomyces lanuginosus MC 134 (Kumar et al., 2009) and Aspergillus niger ANL 301 (Okafor et al., 2007).

In the tests of influence of mixtures (1:1) of substrates, the xylanase production by $A$. niger was $22 \%$ higher on the mixture of wheat bran and corncob when compared to media containing xylan as carbon source. When we compare the xylanase production by $A$. flavus in this mixture, it was almost $45 \%$ lower than from $A$. niger. And comparing the xylanase production between the used fungi in the other mixtures, A. flavus presented a very lower production than $A$. niger.

In literature, different combinations of agroindustrial residues as carbon sources for xylanase production, has been reported for several fungi (Khonzue et al., 2011; Facchini et al., 2011; Dhillon et al., 2011; Pal and Khanum, 2010; Betini et al., 2009; Peixoto-Nogueira et al., 2009). Aspergillus niger DFR-5 had his highest xylanase production in media containing a mixture of wheat bran and soybean powder in a ratio 7:3 (Pal and Khanum, 2010), while Aspergillus niger BC-1 mixed with T. reesei Rut C-30 (ATCC 56765) had the highest activity with rice straw and wheat bran (3:2) (Dhillon et al., 2011). Facchini et al. (2011) found that a mixture of soybean meal and crushed corncob increased xylanolytic activity by only $8.5 \%$. And in work using the fungus $A$. niveus and some agroindustrial residues, wheat bran mixed with corncob not improved the production of xylanase, but $A$. niger and $A$. ochraceus had an increase of approximately $20 \%$ (Betini et al., 2009).

For the enzyme characterization and the biobleaching study, there were separated the filtrates that more produced enzymes. And the cellulase activity of theses filtrates was determined and did not detect significant levels (data not shown).

\section{Effect of temperature and $\mathrm{pH}$ on xylanase stability}

The xylanases produced by $A$. niger and $A$. flavus remained totally stable at $45^{\circ} \mathrm{C}$. At $50^{\circ} \mathrm{C}$ both xylanases were stable for the first twenty minutes, where the xylanase of $A$. niger (Figure 1A) still retained $85.72 \%$ activity with 2 hours of incubation, and A. flavus (Figure 1B) had a half-life of more than 75 minutes. At $55^{\circ} \mathrm{C}$, the xylanase produced by $A$. niger showed more stable than from $A$. flavus showing a half-life of approximately 45 minutes. In studies with $A$. casielus (Kronbauer et al., 2007), A. phoenicis (Chipeta et al., 2005) and A. giganteus (Coelho and Carmona, 2003) the xylanases had half-life of only 50, 25 and 13 minutes at $50^{\circ} \mathrm{C}$, respectively. The xylanase produced by $A$. terreus FSS129 had a residual activity of only $70 \%$ approximately with 2 hours of incubation at $50^{\circ} \mathrm{C}$, and just retained $25.4 \%$ activity at $55^{\circ} \mathrm{C}$ after 1 hour exposure, while our $A$. niger still retained $38.2 \%$ activity (Bakri et al., 2010). And at $55^{\circ} \mathrm{C}$ the xylanase of $A$. casielus had a half-life of only 17 minutes (Kronbauer et al., 2007).

The influence of glycerol and polyethyleneglycol as enzyme protectors was also tested (Figure 1C,D). The addition of $5 \%$ glycerol somehow protected significantly the xylanase produced by $A$. niger from thermal inactivation at $55^{\circ} \mathrm{C}$ during all the incubation period. The xylanase activity increased $20.66 \%$ with 2 hours of incubation when compared to the control (without additives), and it was observed a half-life of approximately 32 minutes to the control and 60 minutes with glycerol (Figure $1 \mathrm{C}$ ). And the xylanase activity of A. flavus increased $30 \%$ with 2 hours of incubation at $50^{\circ} \mathrm{C}$ in the presence of glycerol, which was not sufficient time to get the enzyme half-life (Figure 1D). The polyethyleneglycol was not effective as protector for both enzymes.

Regarding $\mathrm{pH}$ stability, it was verified that the xylanase from $A$. niger (Figure $1 \mathrm{E}$ ) was totally stable at all the $\mathrm{pHs}$ tested, retaining more than 95\% activity during 1 hour, while the xylanase from $A$. flavus (Figure 1F) had a small decrease of $10 \%$ at $\mathrm{pH}$ between 3.0 - 5.5, maintaining stable $(100 \%)$ at higher pHs. The stability of the xylanases of $A$. niger and $A$. flavus under alkaline $\mathrm{pH}$ is very interesting when we remember that the biobleaching process with xylanases is done under alkaline conditions. Michelin et al. (2010) related a xylanase produced by $A$. terricola Marchal and $A$. ochraceus that retained more than $70 \%$ of 

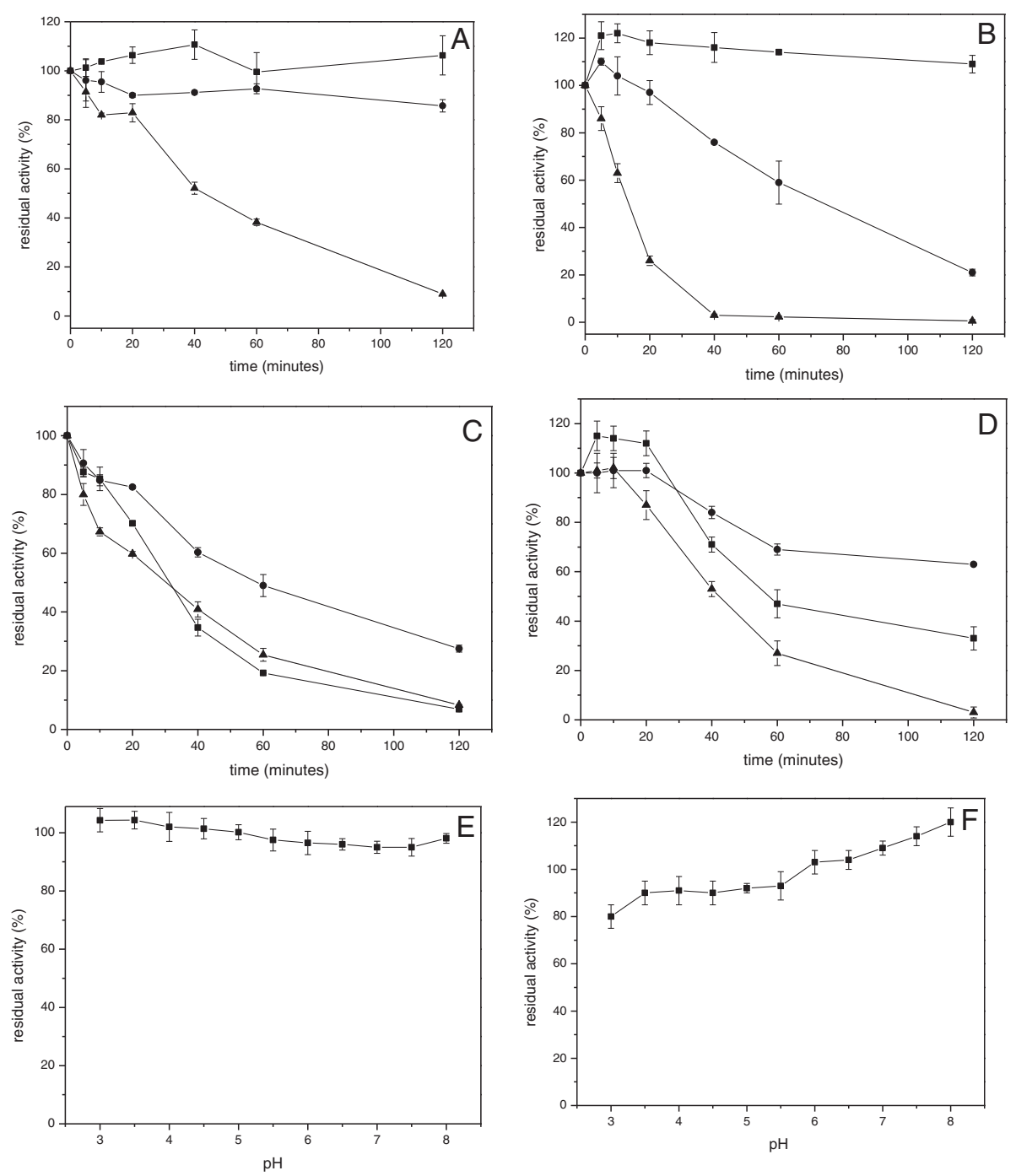

Figure 1 Characterization of the xylanases from A. niger and A. flavus. Thermostability of the xylanase of A. niger (A) and A. flavus (B) were determined using Mcllvaine buffer $\mathrm{pH} 5.0$ at $60^{\circ} \mathrm{C}$ after incubating the enzymes on temperatures of $45(\mathbf{\bullet}), 50(\bullet)$ and $55^{\circ} \mathrm{C}(\boldsymbol{\Lambda})$. Thermostability of the xylanases at 55 (A. niger) (C) and $50^{\circ} \mathrm{C}$ (A. flavus) (D), without additives ((-), and with $5 \%$ glycerol $(\bullet)$ and polyethyleneglycol $(\mathbf{\Delta})$. pH stability of $A$. niger $(\mathbf{E})$ and $A$. flavus $(\mathbf{F})$ were determined incubating both enzymes at different pHs $(3.0-8.0)$ at $0^{\circ} \mathrm{C}$, during 1 hour and after the residual activities were determined at $60^{\circ} \mathrm{C}, \mathrm{pH}$ 5.0.

its original activity in a $\mathrm{pH}$ range of $2.5-8.0$ for 1 hour. The xylanase produced by $A$. fumigatus was stable just in $\mathrm{pH}$ from 6.0 to 8.0, while the xylanase from $A$. niveus was more stable from 4.5 to 6.0 (Peixoto-Nogueira et al., 2009). The xylanases of $A$. niger, $A$. niveus and $A$. ochraceus were stable in the range of $\mathrm{pH} 2-7$ retaining more than $70-80 \%$ activity (Betini et al., 2009).

\section{Assays of cellulose biobleaching using xylanase}

To analyze the xylanases efficiency for cellulose pulp biobleaching assay, the cellulose pulp was clarified by $A$. flavus or $A$. niger crude extract. The procedures occurred
Table 2 Properties of pulp treated with xylanases produced by $A$. niger and $A$. flavus

\begin{tabular}{lccc}
\hline Parameters & Control & A. niger & A. flavus \\
\hline Kappa number & 13.96 & 10.34 & 8.89 \\
Kappa efficiency (\%) & - & 25.93 & 36.32 \\
CST (\%) & 21.70 & 21.30 & 21.60 \\
A $_{237 \mathrm{~nm}}$ & - & 0.093 & 0.120 \\
A $_{465 \mathrm{~nm}}$ & - & 0.056 & 0.062 \\
\hline
\end{tabular}

Biobleaching of bagasse pulp with $10 \mathrm{U}$ xylanase $\mathrm{g}^{-1}$ of pulp in $0.5 \mathrm{M}$ sodium citrate buffer $(\mathrm{pH} 6.5)$ at $55^{\circ} \mathrm{C}$ for $2 \mathrm{~h}$. 
at $55^{\circ} \mathrm{C}$ for $2 \mathrm{~h}$ and it was observed that the xylanase crude extract from A. flavus was more effective in comparison to A. niger. The kappa number reduced 5.07 and 3.62 points, respectively, which corresponds to 36.32 and 25.93 kappa efficiency, respectively (Table 2).

This efficiency can be also proved by cromophores liberation, which was redden at 237 and $465 \mathrm{~nm}$ and again was bigger when the cellulose pulp was clarified by A. flavus crude extract. That is important to emphasize that the cellulase activity was either analyzed and significant levels were not detected (data not shown), which explain why the viscosity was not significantly modified.

Comparing the used fungi that is clear that the xylanase from $A$. flavus is more effective in comparison to xylanase from $A$. niger. These advantages can also be seen when you compare the obtained results for $A$. flavus and $A$. niger to some data from the literature. The xylanase of $A$. caespitosus (10 U/g dry pulp/ 2 hours) reduced kappa number only in $12.6 \%$ (xyl II) and 1.7\% (xyl I) (Sandrim et al., 2005), while the A. flavus and A. niger xylanases kappa efficiency corresponded to 36.32 and 25.93\%, respectively. Medeiros et al. (2007) reported xylanases from $T$. longibrachiatum, $P$. corylophilum and $A$. niger that reduced only $1.1,0.5$ and 0.6 points the kappa number with $5 \mathrm{U} / \mathrm{g}$ dry pulp/ 4 hours; and Aspergillus fumigatus ABK9 reduced only 0.7, 1.2, 2.7, 3.3 and 4 points the kappa number, using 20, 40, 60, 80 and 100 U/g dry pulp/ 6 hours, respectively (Das et al., 2013). And Kumar et al. (2009) reported a xylanase (50 U/g dry $\mathrm{pulp} / 3$ hours) from T. lanuginosus MC 134 that reduced only 3.2 points the kappa number.

\section{Conclusions}

$A$. niger and $A$. flavus showed that are good xylanase producers and these enzymes can be obtained using alternative carbon sources such as wheat bran, corncob and fine sugarcane bagasse, that is important to emphasize that the xylanase production increased when a mix of residues was used, showing a better production than on media supplemented only by xylan, proving that they can substitute the specific substrate and consequently reduce the enzyme production cost, since the commercial xylan is extremely expensive for widespread use. The xylanase from A. niger showed to be stable for temperature and $\mathrm{pH}$, while the A. flavus xylanase was not so stable for temperature but showed excellent stability at high $\mathrm{pH}(6-8)$, characteristics that are very important for the biobleaching of cellulose pulp process. On biobleaching assay the xylanases from $A$. flavus were more effective in comparison to xylanases from $A$. niger.

\section{Competing interests}

The authors declare that they have no competing interests.

\section{Authors' contributions}

NCAG: enzyme production and biobleaching processes, discussion of results, drafted the manuscript; MS: discussion of results; SCPN:biobleaching processes, drafted the manuscript, discussion of results; JHAB: biobleaching processes for pulp; FFZ: drafted the manuscript, discussion of results; MRM: drafted the manuscript; MLTMP: discussion of results, drafted the manuscript; GCG: discussion of results, drafted the manuscript. All authors read and approved the final manuscript.

\section{Acknowledgements}

This work was supported by grants from Conselho de Desenvolvimento Científico e Tecnológico (CNPq). This work was part of Master Dissertation of NCAG (Laboratório de Bioquímica / CCBS, Universidade Federal de Mato Grosso do Sul, Campo Grande, MS, Brasil). The authors gratefully for the support from the USP/Ribeirão Preto - SP, Brazil.

\section{Author details}

${ }^{1}$ Laboratory of Biochemistry, CCBS - Universidade Federal de Mato Grosso do Sul/UFMS, Av Costa e Silva s/n²,79070-900, Campo Grande, MS, Brazil.

${ }^{2}$ Department of Biology, Faculdade de Filosofia, Ciências e Letras de Ribeirão Preto, Universidade de São Paulo, Av do Café s/nº, 14040-901, Ribeirão Preto, SP, Brazil.

Received: 7 May 2013 Accepted: 29 July 2013

Published: 13 August 2013

\section{References}

Bakri Y, Masson M, Thonart P (2010) Isolation and identification of two new fungal strains for xylanase production. Appl Biochem Biotechnol 162:1626-1634

Betini JHA, Michelin M, Peixoto-Nogueira SC, Jorge JA, Terenzi HF, Polizeli MLTM (2009) Xylanases from Aspergillus niger, Aspergillus niveus and Aspergillus ochraceus produced under solid-state fermentation and their application in cellulose pulp bleaching. Bioprocess Biosyst Eng 32(6):819-824

Birijlall N, Manimaran A, Kumar KS, Permaul K, Singh S (2011) High level expression of a recombinant xylanase by Pichia pastoris NC38 in a $5 \mathrm{~L}$ fermenter and its efficiency in biobleaching of bagasse pulp. Bioresour Technol 102:9723-9729

Chapla D, Divecha J, Madamwar D, Shah A (2010) Utilization of agro-industrial waste for xylanase production by Aspergillus foetidus MTCC 4898 under solid state fermentation and its application in saccharification. Biochem Eng J 49:361-369

Chipeta ZA, Preez JC, Szakacs G, Christopher L (2005) Xylanase production by fungal strains on spent sulphite liquor. Appl Microbiol Biotechnol 69:71-78

Coelho GD, Carmona EC (2003) Xylanolytic complex from Aspergillus giganteus: production and characterization. J Basic Microbiol 43(4):269-277

Das A, Paul T, Halder SK, Jana A, Maity C, Mohapatra PKD, Pati BR, Mondal KC (2013) Production of cellulolytic enzymes by Aspergillus fumigatus ABK9 in wheat bran-rice straw mixed substrate and use of cocktail enzymes for deinking of waste office paper pulp. Bioresour Technol 128:290-296

Dhillon GS, Oberoi HS, Kaur S, Bansal S, Brar SK (2011) Value-addition of agricultural wastes for augmented cellulase and xylanase production through solid-state tray fermentation employing mixed-culture of fungi. Ind Crop Prod 34:1160-1167

Facchini FD, Vici AC, Reis VR, Jorge JA, Terenzi HF, Reis RA, Polizeli MLTM (2011) Production of fibrolytic enzymes by Aspergillus japonicus C03 using agroindustrial residues with potential application as additives in animal feed. Bioprocess Biosyst Eng 34(3):347-355

Facchini FD, Reis VR, Roth AP, Magalhães KA, Peixoto-Nogueira SC, Casagrande DR, Reis RA, Polizeli MLTM (2012) Effects of Aspergillus spp. exogenous fibrolytic enzymes on in vitro fermentation of tropical forages. J Sci Food Agric 92:2569-2573

Farinas CS, Loyo MM, Junior AB, Tardioli PW, Neto VB, Couri S (2010) Finding stable cellulase and xylanase: evaluation of the synergistic effect of $\mathrm{pH}$ and temperature. N Biotechnol 27(6):810-815

Fengxia L, Mei L, Zhaoxin L, Xiaomei B, Haizhen Z, Yi W (2008) Purification and characterization of xylanase from Aspergillus ficuum AF-98. Bioresour Technol 99:5938-5941

Garg G, Mahajan R, Kaur A, Sharma J (2011) Xylanase production using agro-residue in solid-state fermentation from Bacillus pumilus ASH for biodelignification of wheat straw pulp. Biodegradation 22(6):1143-1154 
Jiang Z, Cong Q, Yan Q, Kumar N, Du X (2010) Characterization of a thermostable xylanase from Chaetomium sp. and its application in Chinese steamed bread. Food Chem 120:457-462

Khonzue P, Laothanachareon T, Rattanaphan N, Tinnasulanon P, Apawasin S, Paemanee A, Ruanglek V, Tanapongpipat S, Champreda V, Eurwilaichitr L (2011) Optimization of xylanase production from Aspergillus niger for biobleaching of eucalyptus pulp. Biosci Biotechnol Biochem 75(6):1129-1134

Kronbauer EAW, Peralta RM, Osaku CA, Kadowaki MK (2007) Produção de xilanase por Aspergillus casielus com diferentes fontes de carbono. B. ceppa Curitiba 25(2):207-216

Kumar KS, Manimaran A, Permaul K, Singh S (2009) Production of $\beta$-xylanase by a Thermomyces lanuginosus MC 134 mutant on corn cobs and its application in biobleaching of bagasse pulp. J Biosci Bioeng 107(5):494-498

Lakshmi GS, Rao CS, Rao RS, Hobbs PJ, Prakasham RS (2009) Enhanced production of xylanase by a newly isolated Aspergillus terreus under solid state fermentation using palm industrial waste: A statistical optimization. Biochem Eng J 48:51-57

Lowry H, Rosebrough NJ, Farr AL, Randal RJ (1951) Protein measurement with the Folin phenol reagent. J Biol Chem 193(1):267-275

Mcllvaine TC (1921) A buffer solution for colorimetric comparison. J Biotechnol 49:183-186

Medeiros RG, Silva FG, Jr, Báo SN, Hanada R, Filho EXF (2007) Application of xylanases from Amazon forest fungal species in bleaching of eucalyptus kraft pulps. Braz Arch Biol Technol 50(2):231-238

Michelin M, Peixoto-Nogueira SC, Betini JH, da Silva TM, Jorge JA, Terenzi HF, Polizeli MLTM (2010) Production and properties of xylanases from Aspergillus terricola Marchal and Aspergillus ochraceus and their use in cellulose pulp bleaching. Bioprocess Biosyst Eng 33(7):813-821

Miller GL (1959) Use of dinitrosalicilic acid reagent for determination of reducing sugar. Anal Chem 31:426-429

Okafor UA, Okochi VI, Onyegeme-okerenta BM, Nwodo-Chinedu S (2007) Xylanase production by Aspergillus niger ANL 301 using agro - wastes. Afr J Biotechnol 6(14):1710-1714

Pal A, Khanum F (2010) Production and extraction optimization of xylanase from Aspergillus niger DFR-05 through solid-state-fermentation. Bioresour Technol 101:7563-7569

Peixoto-Nogueira SC, Michelin M, Betini JHA, Jorge JA, Terenzi HF, Polizeli MLTM (2009) Production of xylanase by Aspergilli using alternative carbon sources: application of the crude extract on cellulose pulp biobleaching. J Ind Microbiol Biot 36:149-155

Polizeli MLTM, Rizzatti ACS, Monti R, Terenzi HF, Jorge JA, Amorim DS (2005) Xylanases from fungi: properties and industrial applications. Appl Microbiol Biotechnol 67:577-591

Rizzatti ACS, Jorge JA, Terenzi HF, Rechia CGV, Polizeli MLTM (2001) Purification and properties of a thermostable extracellular $\beta$-xylosidase produced by thermotolerant Aspergillus phoenicis. J Ind Microbiol Biot 26(3):156-160

Sandrim VC, Rizzatti ACS, Terenzi HF, Jorge JA, Milagres AMF, Polizeli MLTM (2005) Purification and biochemical characterization of two xylanases produced by Aspergillus caespitosus and their potential for kraft pulp bleaching. Process Biochem 40:1823-1828

Sepahy AA, Ghazi S, Sepahy MA (2011) Cost-effective production and optimization of alkaline xylanase by indigenous Bacillus mojavensis AG137 fermented on agricultural waste. Enzyme Res 2011:593-624

Sorgatto M, Guimarães NCA, Zanoelo FF, Marques MR, Peixoto-Nogueira SC, Giannesi GC (2012) Purification and characterization of an extracellular xylanase produced by the endophytic fungus, Aspergillus terreus, grown in submerged fermentation. Afr J Biotechnol 11(32):8076-8084

TAPPI test methods (1996) Technical association of the pulp and paper industry. TAPPI Press, Atlanta, GA

Yeasmin S, Kim CH, Park HJ, Sheikh MI, Lee JY, Kim JW, Back KK, Kim SH (2011) Cell surface display of cellulase activity-free xylanase enzyme on Saccharomyces cerevisiae EBY100. Appl Biochem Biotechnol 164(3):294-304

doi:10.1186/2193-1801-2-380

Cite this article as: de Alencar Guimaraes et al:: Bioprocess and biotechnology: effect of xylanase from Aspergillus niger and Aspergillus flavus on pulp biobleaching and enzyme production using agroindustrial residues as substract. SpringerPlus 2013 2:380.

\section{Submit your manuscript to a SpringerOpen ${ }^{\circ}$ journal and benefit from:}

- Convenient online submission

- Rigorous peer review

- Immediate publication on acceptance

- Open access: articles freely available online

- High visibility within the field

- Retaining the copyright to your article

Submit your next manuscript at springeropen.com 